Vol. 6, No. 1, 2021

\title{
ADVANCED TECHNOLOGIES FOR PROCESSING LIQUID WASTE OF GALURGICAL PRODUCTIONS
}

\author{
Volodymyr Mykhaylenko ${ }^{1}$, Valentyna Yurchenko², Oleksiy Antonov ${ }^{1}$, \\ Olha Lukianova ${ }^{1}$, Zinaida Gil ${ }^{1}$ \\ ${ }^{1}$ A. Podgorny Institute for Mechanical Engineering Problems NAS of Ukraine, \\ 2/10, Pozharskogo Str., Kharkiv, 61046, Ukraine, \\ ${ }^{2}$ Kharkiv National Universityof Civil Engineering and Architecture, \\ 40, Sumskaya Str., Kharkiv, 61002, Ukraine \\ port342017@gmail.com
}

https://doi.org/10.23939/ep2021.01.001

Received: 22.10 .2020

(C) Mykhaylenko V., Yurchenko V., Antonov O., Lukianova O., Gil Z., 2021

\begin{abstract}
The accumulation of highly mineralized waters and brines in the mining-industrial regions of Ukraine carry a threat of salt pollution of underground and surface water sources. Low-waste processing of these waters is prevented by iron compounds, hydrogen sulfide and sulfur-containing organic compounds. The process of accumulation of iron compounds in brines and groundwater in the presence of hydrogen sulfide has been studied. Comparative calculations of the thermodynamic potentials of the corresponding reactions have been carried out. The calculation results are confirmed by experiments on model solutions and brine of the Dombrovsky quarry. To remove iron compounds from brines and other highly mineralized waters, it is proposed to use electrolysis with inert anodes. It was found that $99.9 \%$ of iron compounds pass into the precipitate of iron hydroxide (III). At the same time, the overwhelming amount of heavy metals also passes into the sediment.
\end{abstract}

Key words: brine, iron, groundwater, brine, redox reactions, sulfate reduction, electrolysis, inert anode.

\section{Introduction}

As a result of long-term exploitation of the potash salt deposit in the Kalush mining-industrial region, more than 30 million $\mathrm{m}^{3}$ of highly mineralized brines have been accumulated. These brines are concentrated in the Dombrowsky quarry, mine tailing dumps and mines "subjected to wet conservation" (simply flooded). As a result, this region in 2010 was declared an ecological disaster zone. Brines from tailing dumps, mines and Dombrovsky quarry are gradually seeping into underground aquifers, making the water in them unsuitable for drinking and technical purposes. Calculations of possible environmental damage from uncontrolled discharge of these brines into the Dniester, carried out in accordance with (Metodyka rozrakhunku..., 2009) show that the minimum amount of damage will exceed UAH 2.4 billion. Some of authors propose a technology for processing such brines and converting them into valuable hydromineral raw materials (Javorskij et al., 2012). But such processing, with the production of edible salt and valuable potash fertilizer, is hampered by a significant concentration of iron compounds, hydrogen sulfide and organic sulfur-containing compounds.

A significant part of artesian waters also contains dissolved iron compounds, hydrogen sulfide and organic sulfur-containing compounds, which give the water an unpleasant odor. This complicates the use of such waters in industry and drinking water supply. High concentrations of iron in some mine and quarry waters interfere with their deep processing to obtain the constituent components in the form of commercial products. It is known that the earth's crust contains many rocks with a high content of iron compounds. But the overwhelm ming majority of them are represented by ferric oxides, which are almost insoluble at a $\mathrm{pH}$ of more than 5.0. Groundwater and brines usually have a $\mathrm{pH}$ closer to neutral. Therefore, the determination of the reasons for the accumulation of water-soluble iron

For citation: Mykhaylenko V., Yurchenko V., Antonov O., Lukianova O., Gil Z., 2020. Advanced technologies for processing liquid waste of galurgical productions. Journal Environmental Problems. Vol. 6, No. 1. p. 1-6. DOI: https://doi.org/10.23939/ep2021.01.001 
compounds and the development of methods for their extraction, primarily from brines and highly mineralized mine waters in the presence of significant concentrations of hydrogen sulfide, is an urgent task.

The purpose of the work is to study the reason for the accumulation of iron compounds in groundwater and brines, as well as to develop a method for their removal.

\section{Materials and Methods}

The calculations of the potentials of redox reactions that occur in salt solutions under anaerobic conditions were carried out using the Nernst formula:

$$
\varphi=\varphi_{0}+\frac{R T}{z F} \ln \frac{c_{o x}}{c_{\text {red }}},
$$

where $\varphi$ is the equilibrium potential of the reaction, $\mathrm{mV}$; $\varphi_{0}$ is reaction potential under standard conditions, $\mathrm{mV} ; T$ is the temperature, $\mathrm{K} ; z$ is the number of electrons carried; $F$ is Faraday number, $\mathrm{C} / \mathrm{mol} ; R$ is a universal gas constant, $\mathrm{J} / \mathrm{mol} \cdot \mathrm{K} ; C_{o x}$ and $C_{r e d}$ is concentration of oxidized and reduced forms of substances, $\mathrm{mol} / \mathrm{dm}^{3}$.

The brine sampled in the Dombrovsky quarry at a depth of $42 \mathrm{~m}$ and model solutions with a composition similar to this brine and groundwater of the Buchach horizon (salinity $2.5 \mathrm{~g} / \mathrm{dm}^{3}$ ) were used for the research. The concentrations of the components of the solutions were measured by standard analytical methods.

\section{Results and Discussion}

In sulfate-containing solutions under anaerobic conditions, in the presence of organic substances, microbiological sulfate reduction occurs as a result of the vital activity of bacteria of the genera Desulfovibrioand Desulfotomaculum (Andrejuk et al., 1984) and hydrogen sulfide and organic sulfur-containing compounds accumulate in accordance with the reactions:

$$
\begin{gathered}
\mathrm{SO}_{4}{ }^{2-}+10 \mathrm{H}^{+}+8 \mathrm{e}=\mathrm{H}_{2} \mathrm{~S}+4 \mathrm{H}_{2} \mathrm{O} ; \\
\mathrm{C}_{3} \mathrm{H}_{6} \mathrm{O}_{3}+3 \mathrm{H}_{2} \mathrm{O}-12 \mathrm{e}=3 \mathrm{CO}_{2}+12 \mathrm{H}^{+}
\end{gathered}
$$

At the same time, the solution is also saturated with carbonic acid, which lowers its $\mathrm{pH}$ (Leonova et al., 2018; Kashkak, 2013; Basen et al., 2014; Bozo-Hurtado et al., 2013; de Rezende et al., 2013). Since hydrogen sulfide is extremely little dissociated in a weakly acidic medium, the content of $\mathrm{S}^{2-}$ ions is small, the product of the solubility of $\mathrm{FeS}$ and $\mathrm{FeS}_{2}$ is not achieved, and these sparingly soluble compounds cannot form (Ivanov, 1989).

As an example, we give the characteristics of the brine of the Dombrovsky quarry, Kalush, Ivano-Frankivsk region. (Table 1)/

It can be seen from the table that the brine has a rather low redox potential, its $\mathrm{pH}$ is shifted to the slightly acidic side, not reaching, however, a value of 5.0. The solution, as follows from the analysis results, contains hydrogen sulfide and, possibly, organic sulfur-containing compounds. Therefore, at this $\mathrm{pH}$, ferric compounds will not dissolve. However, the analysis shows that the solution contains ferrous iron compounds in the ionic form. According to the Purbet diagram for iron compounds (Kul'skij et al., 1986), under these conditions, ferrous ions are stable.

Table 1

\section{The composition of the brine Dombrowsky quarry}

\begin{tabular}{|c|c|c|}
\hline \multirow{2}{*}{ Component name } & \multicolumn{2}{|c|}{ Concentration } \\
\cline { 2 - 3 } & massive & equivalent \\
\hline Soluble iron, $\mathrm{mg} / \mathrm{dm}^{3}$ & 30 & - \\
\hline $\begin{array}{c}\text { Hydrogen sulfide and organic } \\
\text { sulfides in terms of sulfur, } \mathrm{mg} / \mathrm{dm}^{3}\end{array}$ & 15 & - \\
\hline Sodium chloride, $\mathrm{g} / \mathrm{dm}^{3}$ & 227.273 & 3.885 \\
\hline Magnesium chloride, $\mathrm{g} / \mathrm{dm}^{3}$ & 48.83 & 1.028 \\
\hline Magnesium sulfate, $\mathrm{g} / \mathrm{dm}^{3}$ & 46.68 & 0.778 \\
\hline Potassium sulfate, $\mathrm{g} / \mathrm{dm}^{3}$ & 67.686 & 0.778 \\
\hline Water, $\mathrm{g} / \mathrm{dm}^{3}$ & 863.808 & - \\
\hline Brine density, $\mathrm{g} / \mathrm{dm}^{3}$ & 1253 & - \\
\hline Total mineralization, $\mathrm{g} / \mathrm{dm}^{3}$ & 390.5 & 6.469 \\
\hline $\mathrm{pH}$ & 5.7 & - \\
\hline$\varphi, \mathrm{mV}$ & 46 & - \\
\hline
\end{tabular}

In our opinion, the accumulation of iron in brines and groundwater occurs in this way. The solution, which contains hydrogen sulfide and organic sulfides, comes into contact with insoluble iron-containing rocks, which are found in significant quantities in the earth's crust. In this case, ferric iron compounds are reduced to ferrous by the reaction:

$$
\mathrm{Fe}_{2} \mathrm{O}_{3}+3 \mathrm{H}_{2} \mathrm{O}+2 \mathrm{e}=2 \mathrm{Fe}(\mathrm{OH})_{2}+2 \mathrm{OH}^{-}
$$

The equilibrium potential of this reaction, calculated by the formula (1) using standard electrode potentials [Dobosh 1989], taking into account the iron concentration in the solution of $30 \mathrm{mg} / \mathrm{dm}^{3}$, is $581 \mathrm{mV}$.

At the same time, hydrogen sulfide and organic sulfides contained in the brine are oxidized according to the reaction [Javorskij et al. 2012]:

$$
\mathrm{H}_{2} \mathrm{~S}+3 \mathrm{H}_{2} \mathrm{O}-6 \mathrm{e}=\mathrm{SO}_{3}{ }^{2-}+8 \mathrm{H}^{+}
$$

The equilibrium potential of reaction (5), taking into account the concentration of hydrogen sulfide in the solution of $15 \mathrm{mg} / \mathrm{dm}^{3}$ and $\mathrm{pH}=6.0$, is $(-500) \mathrm{mV}$. Thus, the potential difference in reactions (4) and (5) exceeds $1 \mathrm{~V}$, which is quite enough for their spontaneous occurrence.

The resulting sulfite ion $\mathrm{SO}_{3}{ }^{2-}$ is used by sulfatereducing bacteria for the oxidation of organic substances according to reactions (3) and (5).

Iron (II) hydroxide obtained in the reaction (4) reacts with carbon dioxide to form soluble iron bicarbonate $\mathrm{Fe}\left(\mathrm{HCO}_{3}\right)_{2}$.

All the reactions described proceed at a low rate. We have calculated the thermodynamic parameters of the oxidation reactions of acetic acid (since the thermodynamic 
parameters of lactic acid are absent in the reference literature (Mishhenko et al., 1974)) with sulfates (6) and air oxygen (7).

$$
\begin{gathered}
\mathrm{C}_{2} \mathrm{H}_{4} \mathrm{O}_{2}+\mathrm{Na}_{2} \mathrm{SO}_{4}=2 \mathrm{CO}_{2}+\mathrm{Na}_{2} \mathrm{~S}+2 \mathrm{H}_{2} \mathrm{O} \\
\mathrm{C}_{2} \mathrm{H}_{4} \mathrm{O}_{2}+2 \mathrm{O}_{2}=2 \mathrm{CO}_{2}+2 \mathrm{H}_{2} \mathrm{O}
\end{gathered}
$$

The process of sulfate reduction proceeds with a small release of free energy (for acetate acid $\Delta \mathrm{G}_{298}=$ $=-31.6 \mathrm{~kJ} / \mathrm{mol}$ ) in comparison with aerobic oxidation of the same acid $\left(\Delta \mathrm{G}_{298}=-882.8 \mathrm{~kJ} / \mathrm{mol}\right)$. Accordingly, the rate of sulfate reduction is low. Reduction of trivalent compounds with iron-hydrogen sulfide and further dissolution of ferrous hydroxide in a solution saturated with carbonic acid are solid-phase reactions with diffusion rate limitation. It is the low rate of the noted reactions that explains the decrease in the concentration of iron, and subsequently, of hydrogen sulfide, which is observed in the water of artesian wells with prolonged pumping of water.

For experimental confirmation of the mechanism proposed above for the accumulation of soluble iron compounds in brines and groundwater, the studies were carried out on model solutions. Their composition is shown in Tables 2 and 3.

Table 2

Composition of the solution simulatings groundwater

\begin{tabular}{|c|c|c|}
\hline \multirow{2}{*}{ Component name } & \multicolumn{2}{|c|}{ Concentration } \\
\cline { 2 - 3 } & massive & equivalent \\
\hline $\begin{array}{c}\text { Hydrogen sulfide in terms } \\
\text { of sulfur, } \mathrm{mg} / \mathrm{dm}^{3}\end{array}$ & 15 & - \\
\hline Sodium chloride, $\mathrm{g} / \mathrm{dm}^{3}$ & 1.5 & 0.026 \\
\hline Magnesium chloride, $\mathrm{g} / \mathrm{dm}^{3}$ & 0.5 & 0.011 \\
\hline Sodium sulfate, $\mathrm{g} / \mathrm{dm}^{3}$ & 0.5 & 0.007 \\
\hline Total mineralization, $\mathrm{g} / \mathrm{dm}^{3}$ & 2.5 & 0.044 \\
\hline $\mathrm{pH}$ & 5.7 & - \\
\hline$\varphi, \mathrm{mV}$ & 270 & - \\
\hline
\end{tabular}

The composition of the solution simulating the brine of the Dombrowsky quarry

\begin{tabular}{|c|c|c|}
\hline \multirow{2}{*}{ Component name } & \multicolumn{2}{|c|}{ Concentration } \\
\cline { 2 - 3 } & massive & equivalent \\
\hline $\begin{array}{c}\text { Hydrogen sulfide in terms of } \\
\text { sulfur, } \mathrm{mg} / \mathrm{dm}^{3}\end{array}$ & 15 & - \\
\hline Sodium chloride, $\mathrm{g} / \mathrm{dm}^{3}$ & 221 & 3.761 \\
\hline Magnesium chloride, $\mathrm{g} / \mathrm{dm}^{3}$ & 49 & 1.032 \\
\hline Sodium sulfate, $\mathrm{g} / \mathrm{dm}^{3}$ & 110 & 1.549 \\
\hline Water, $\mathrm{g} / \mathrm{dm}^{3}$ & 869 & - \\
\hline Brine density, $\mathrm{g} / \mathrm{dm}^{3}$ & 1248 & - \\
\hline Total mineralization, $\mathrm{g} / \mathrm{dm}^{3}$ & 380 & 6.342 \\
\hline $\mathrm{pH}$ & 5.7 & - \\
\hline$\varphi, \mathrm{mV}$ & \multicolumn{2}{|c|}{270} \\
\hline
\end{tabular}

The solutions were prepared as follows.

Solution № $1.2 \mathrm{~g}$ of sodium bicarbonate, $0.5 \mathrm{~g}$ of sodium chloride and $0.5 \mathrm{~g}$ of sodium sulfate were dissolved in $1 \mathrm{dm}^{3}$ of distilled water (deoxygenated by boiling). Then
$40 \mathrm{mg}$ of sodium sulfide was added, and the brine was neutralized with hydrochloric acid to $\mathrm{pH}=5.7$.

Solution № $2.110 \mathrm{~g}$ of sodium sulfate. $2 \mathrm{~g}$ of sodium bicarbonate, $49 \mathrm{~g}$ of magnesium chloride and 220 $\mathrm{g}$ of sodium chloride were dissolved in $869 \mathrm{~cm}^{3}$ of distilled water (with the preliminary exclusion of oxygen by boiling). $40 \mathrm{mg}$ of sodium sulfide were added, and the brine was neutralized with hydrochloric acid to $\mathrm{pH}=5.7$. The resulting solutions were stored in a sealed container, having previously measured their parameters (density and $\varphi$ ).

The experiments were carried out as follows. The prepared model solutions with a volume of $0.5 \mathrm{dm}^{3}$, together with $2 \mathrm{~g}$ of freshly precipitated ferric hydroxide, were stirred with a magnetic stirrer in a beaker with a sealed lid. $\varphi$ was monitored and maintained by the addition of sodium sulfide and the $\mathrm{pH}$ by the addition of hydrochloric acid. During the experiment, the concentration of iron in the solution was determined at regular intervals. To determine the concentration of iron, a standard method with o-phenanthroline was used. As a control, an experiment was carried out using solution №1 without adding sodium sulfide to it $(\mathrm{Eh}=580 \mathrm{mV})$. The experimental results are shown in Fig. 1.

The next experiment was carried out on solution № 2 similar to the previous ones, but instead of ferric hydroxide, $2 \mathrm{~g}$ of ground Kryvyi Rig red hematite was added to the solution. This experiment was carried out around the clock with online monitoring of $\mathrm{pH}$ and Eh. The experimental results are shown in Fig. 2.

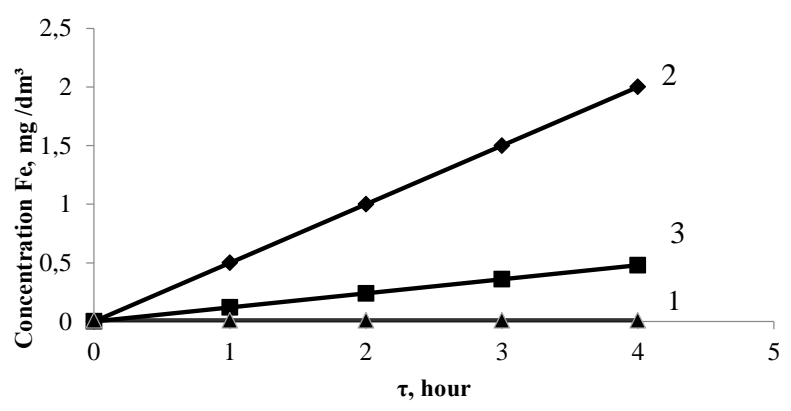

Fig. 1. Accumulation of soluble iron compounds in model solutions upon their contact with iron (III) hydroxide:

1 - solution №1 without adding sodium sulfide; 2 -solution № 1; 3 - solution № 2

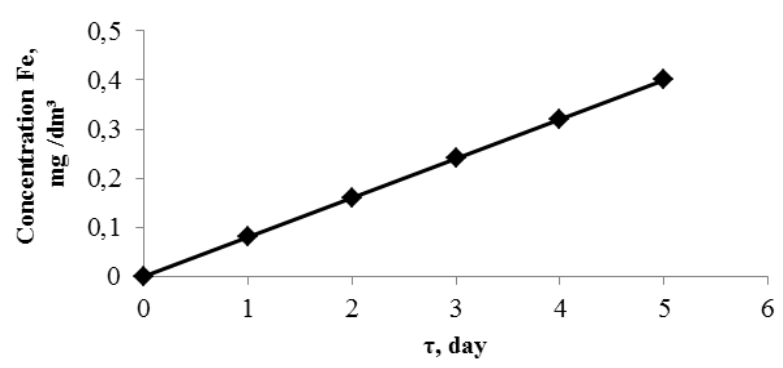

Fig. 2. Accumulation of soluble iron compounds in a model brine (solution 2) upon contact with Kryvyi Rig red hematite 
As can be seen from the given graphs, if there is no hydrogen sulfide in the solution, then upon its contact with iron (III) hydroxide, the accumulation of soluble forms of iron does not occur. In the other three experiments, a gradual increase in the concentration of iron ions was observed. This process took place most rapidly at a low salinity of the solution, which is explained by the higher solubility and, accordingly, the higher degree of dissociation of substances in diluted solutions. The lowest speed of accumulation of ferrous iron ions was observed when using Kryvyi Rig red hematite, since in this case a slowed down previous stage is added to reactions (2), (3) and (4) - surface hydration of iron oxide (III). Thus, the decisive role of sulfate reduction in the accumulation of iron in the composition of groundwater and deep brines is shown.

An additional proof of the correctness of the mechanism of the processes noted is the negative dependence of the depth at which iron compounds and hydrogen sulfide appear in solutions on the growth of their mineralization, which prevents the dissolution of atmospheric oxygen. So, in the Black Sea (mineralization $-15-25 \mathrm{~g} / \mathrm{dm}^{3}$ ), the depth of the beginning of hydrogen sulfide layers is $150 \mathrm{~m}$, and in the Dombrovsky quarry (mineralization $-300-400 \mathrm{~g} / \mathrm{dm}^{3}$ ) a similar zone begins already at a depth of $40 \mathrm{~m}$.

To remove iron compounds from solutions, it is necessary to pre-oxidize and remove hydrogen sulfide and organic sulfides from them. However, this is not a problem only for low-mineralized waters, since they can be oxidized by atmospheric oxygen. In the case of highly mineralized waters and brines, this well-known process is impossible since oxygen hardly dissolves in such media. With such treatment of brines, the redox potential is insufficient for the oxidation of hydrogen sulfide to sulfates and even to water-soluble sulfites. In this case, hydrogen sulfide is oxidized to colloidal sulfur which is gradually removed into the sediment together with iron (III) hydroxide, cementing the latter. As a result, stony deposits are formed on the surface of the equipment, which is problematic to clean. Even the preliminary treatment of the solution in the ejector under the simultaneous action of a magnetic field does not eliminate the deposits, despite the formation of small amounts of strong oxidants during such treatment (Mihajlenko et al., 2019).

The problem of deferrization of highly mineralized waters and brines can be solved by using a strong oxidizing reagent (for example, sodium hypochlorite). However, the reagent method of brine oxidation has a number of significant disadvantages, in particular, the high cost of the reagents, the severity of the dosing process control and the possibility of contamination of the original brine. In addition, iron (III) hydroxide is formed in the form of a sol during the treatment of brine with sodium hypochlorite, and for its rapid coagulation, the oxidized brine must be heated to a temperature of at least $50^{\circ} \mathrm{C}$. Therefore, we proposed to use a reagent-free electrolysis process for the oxidation of hydrogen sulfide and iron in the brine of the Dombrovsky quarry using a previously developed inert anode (Mykhailenko et al., 2015). The studies were carried out on a laboratory electrolyzer with an anode which consisted of a titanium base with a thin layer of manganese dioxide deposited on it, which then was sequentially covered with a thick layer of lead dioxide, first from an alkaline complex, and then from nitrate electrolytes.

The density of the anodic current was $50 \mathrm{~A} / \mathrm{m}^{2}$. The results of the study of the removal of iron compounds from the marked brine are shown in the graph (Fig. 3). The presented data indicate that when the redox potential of $726 \mathrm{mV}$ (500 mV with relative to the silver-chloride reference electrode) is reached, the residual concentration of soluble iron compounds in the brine becomes below $0.05 \mathrm{mg} / \mathrm{dm}^{3}$. In general, the concentration of iron in brine is reduced more than 600 times. Unlike reagent oxidation, the electrolysis process is easily regulated, while as a result of the significantly higher activity of the formed oxidant, the process can be stopped without reaching a significant excess of oxidant in the brine. Moreover, iron (III) hydroxide with this processing method is formed immediately in the form of coagulated flakes, which facilitates their subsequent removal by filtration without preheating.

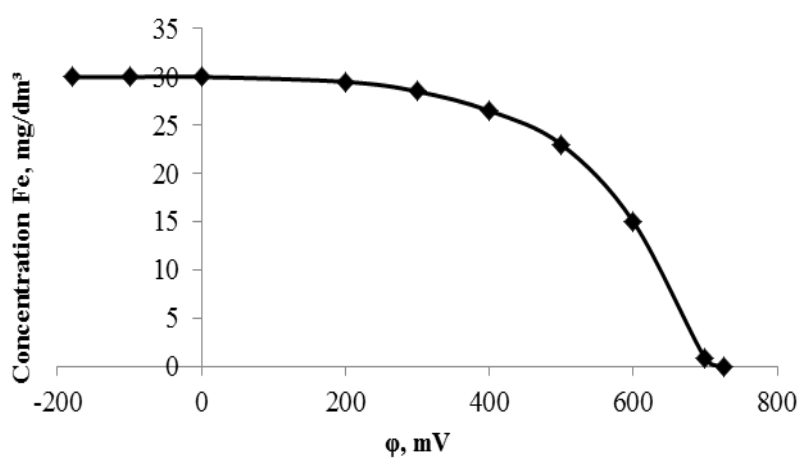

Fig. 3. Dependence of the residual concentration of soluble iron compounds, $\mathrm{mg} / \mathrm{dm}^{3}$, on the redox potential of the brine, $\mathrm{mV}$

At the same time, it was found that the treatment of brine in an electrolyzer with an insoluble anode and subsequent filtration lead to the concomitant removal of heavy metals from it (Table 4). 
During electrolysis, $4.8 \mathrm{dm}^{3}$ of brine was removed from iron compounds and heavy metals. The analyzes carried out by inductively coupled plasma atomic emission spectrometry on a PlasmaQant PQ 9000 Elite device showed that the overwhelming amount of copper and cadmium of the initial brine passes into the precipitate of iron (III) hydroxide. Crystalline sodium chloride and mother liquor containing potassium and magnesium compounds obtained as a result of processing purified brine are practically free from impurities of cadmium and copper (Table 5).

\section{Table 4}

\section{Heavy metals in Dombrowsky open pit brine} and its cleaning products

\begin{tabular}{|l|c|c|c|c|}
\hline Metal & $\begin{array}{c}\text { MPC, } \\
\mathrm{mg} / \mathrm{dm}^{3} \\
\text { in sea } \\
\text { water }\end{array}$ & $\begin{array}{c}\text { Actual } \\
\text { content in } \\
\text { the original } \\
\text { brine, } \\
\mathrm{mg} / \mathrm{dm}^{3}\end{array}$ & $\begin{array}{c}\text { Iron } \\
\text { hydroxid } \\
\text { e content } \\
\text { in the } \\
\text { sediment, } \\
\mathrm{mg}\end{array}$ & $\begin{array}{c}\text { Concentr } \\
\text { ation in } \\
\text { purified } \\
\text { brine, } \\
\mathrm{mg} / \mathrm{dm}^{3}\end{array}$ \\
\hline Zinc & 1.0 & 0.12 & - & - \\
\hline Copper & 0.01 & $\mathbf{0 . 1 1}$ & 0.515 & 0.0029 \\
\hline Mercury & 0.0001 & 0.00005 & - & - \\
\hline Lead & 0.03 & $<0.05$ & - & - \\
\hline Cadmium & 0.001 & $\mathbf{0 . 0 0 3 3}$ & 0.013 & 0.00059 \\
\hline Chromium & 0.07 & 0.055 & - & - \\
\hline
\end{tabular}

Table 5

\section{The content of heavy metals in sodium chloride and mother liquor}

\begin{tabular}{|c|c|c|}
\hline Metal & $\begin{array}{c}\text { Mass fraction, \%, } \\
\text { in sodium chloride }\end{array}$ & $\begin{array}{c}\text { Concentration in } \\
\text { mother liquor, } \\
\mathrm{mg} / \mathrm{dm}^{3}\end{array}$ \\
\hline Cadmium & 0.0000093 & $<0.0005$ \\
\hline Copper & 0.0000082 & 0.0062 \\
\hline
\end{tabular}

The presented data indicate that the concentration of copper in the brine during the mentioned treatment decreases 38 times, cadmium - more than 6 times.

\section{Conclusions}

As a result of theoretical and experimental studies, a mechanism for the accumulation of iron compounds in groundwater and brines under anaerobic conditions has been proposed. The described mechanism involves the gradual reduction of insoluble $\mathrm{Fe}^{3+}$ compounds with hydrogen sulfide and the further formation of soluble ferrous bicarbonate. Based on the disclosed mechanism, a non-reagent method has been developed for removing iron and hydrogen sulfide compounds from brines and highly mineralized waters by electrolysis using an inert anode. This method can be applied to purify quarry brines and highly mineralized natural, mine and wastewaters before their low-waste processing. Simultaneously with iron compounds and hydrogen sulfide, heavy metals are also extracted from the brine. The implementation of the proposed method will allow the introduction of low-waste technologies for processing brines accumulated in the mining regions of Ukraine and, thus, reduce the risk of pollution of underground and surface water sources.

The above results were obtained during the research work "Improving the environmental friendliness and reliability of power units with supercritical steam parameters through the creation of resource-saving water treatment technology" which is carried out within the framework of the target program of scientific research of the National Academy of Sciences of Ukraine "Intelligent environmentally friendly energetics with traditional and renewable energy sources" ("New Energy") for 2019-2021.

\section{References}

Andrejuk, E. I., Bilaj V. I., Koval', Je. Z. \& Kozlova, I. A. (1980). Mikrobnaja korrozija i ee vozbuditeli. Kiev: Naukova Dumka. [in Ukrainian]

Basen, M., Krüger, M., Milucka, J., Kuever, J., Kahnt, J., Grundmann, O., Meyerdierks, A., Widdel, F. \& Shima, S. (2011). Bacterialen zymes for dissimilatory sulfatereduction in a marine microbialmat (Black Sea) mediating an aerobic oxidation of methane. Environmental Microbiology, 13(5), 1370-1379. doi: https://doi.org/ 10.1111/ j.14622920.2011.02443.x

Bozo-Hurtado, L., García-Amado, M. A., Chistoserdov, A., Varela, R., Narvaez, J. J., Colwell, R., \& Suárez, P. (2013). Identification of bacteria in enrichment cultures of sulfate reducers in the Cariaco Basin water column employing Denaturing Gradient Gel Electrophoresis of 16S ribosomal RNA gene fragments. Aquatic Biosystems, (9), 17. doi: https://doi.org/10.1186/2046-9063-9-17

Dobosh, D. (1980). Jelektrohimicheskie konstanty. M.: Mir. [in Russian]

de Rezende, J. R., Kjeldsen, K. U., Hubert, C. R., Finster K., Loy, A. \& Jørgensen, B. B. (2013). Dispersal of thermophilic Desulfotomaculum endospores into Baltic Sea sediments over thousands of years. ISME Journal: Multidisciplinary Journal of Microbial Ecology, 2013, 7 (1), 72. doi: http://dx.doi.org/10.1038/ismej.2012.83.

Ivanov M. V. (red.) (1989). Jevoljucija global'nogo biogeohimicheskogo cikla sery. M.: Nauka. ISBN 5-02004033-9. [in Russian]

Javorskij, V. T., Perekupko, T. V., Blazhivskij, K. I., Maksimovich I. E. \& Perekupko, A. V. (2012). Pererabotka rastvorov hvostohranilishh kalijnyh proizvodstv Prikarpat'ja $\mathrm{v}$ kondicionnye produkty. Jenergotehnologii $i$ resursosberezhenie, (5), 71-75. [in Ukrainian] 
Kashkak, E. S. (2013). Sul'fatvosstanavlivajushhie bakterii mineral'nyh istochnikov Hojto-Gol. Vestnik Burjatskogo gosudarstvennogo universiteta, (4), 153-155. [in Russian]

Kul'skij, L. A., \& Strokach, P. P. (1986). Tehnologija ochistki prirodnyh vod. Kiev: Vishha shkola. Golovnoe yzdatelstvo. [in Ukrainian]

Leonova, G. A., Mal'cev, A. E., Melenevskij, V. N., Miroshnichenko, L. V., Kondrat'eva, L. M., \& Bobrov, V. A. (2018). Geohimija diageneza organogennyh osadkov na primere malyh ozer juga Zapadnoj Sibiri i Pribajkal'ja. Geohimija, (4), 363-382. [in Russian]

Metodyka rozrakhunku rozmiriv vidshkoduvannia zbytkiv, zapodiianykh derzhavi vnaslidok porushennia zakonodavstva pro okhoronu ta ratsionalne vykorystannia vodnykh resursiv. Ministerstvo zakhystu dovkillia ta pryrodnykh resursiv Ukrainy. (2009). Retrieved from https://mepr.gov.ua/content/metodiki-rozrahunkurozmiriv-vidshkoduvannya-zbitkiv.html [in Ukrainian]

Mishhenko, K. P., \& Ravdel', A. A. (red.) (1974). Kratkij spravochnik fiziko-himicheskih velichin. L.: Himija. [in Russian]

Mihajlenko, V. G., Luk'janova, O. I., \& Gil', Z. P. (2019). Poluchenie okislitelej s ispol'zovaniem fizicheskih polej. Visnyk NTU "KhPI". Seriia: Novi rishennia $v$ suchasnykh tekhnolohiiakh, 5(1330), 139-144. doi: https://doi.org/ 10.20998-2413-4295.2019.05.18 [in Ukrainian]

Mykhailenko, V. H., Tarelin, A. O., Kniazieva, O. I., Lukianov, Ye. F., Khinievych, O. Ye. \& Hil, Z. P. (2015). UA. Patent No.108185. Kyiv, Derzhavne pidpryiemstvo Ukrainskyi instytut intelektualnoi vlasnosti. [in Ukrainian] 